\title{
The New Old Lawyer: How Lawyers have Adapted to Mediation to Preserve their Power, Income, and Identity
}

\author{
Paper Presented at the Asian Mediation Association Conference \\ Kuala Lumpur, February 2011
}

Archie Zariski, BA, LLB, LLM, C Med

Associate Professor, Athabasca University, Canada

\section{Introduction}

The grassroots of the bar, those lawyers who pursue what has been called "ordinary litigation", have not historically been supporters of alternative dispute resolution (ADR) in general, or mediation in particular. Instead, it has been elite lawyers such as leaders of the organized bar, some judges, community activists, and legal academics who have championed mediation. Some notable examples are several Presidents of the American Bar Association, former Chief Justice of the United States Warren Burger, Judge Wayne Brazil of California, Justice Louise Otis in Canada, former judge Sir Laurence Street in Australia, and Professors Frank Sander, Carrie Menkel-Meadow, Julie Macfarlane, Laurence Boulle, and Tania Sourdin, to name a few.

The situation in Malaysia is no different. For over a decade the Malaysian Bar Council and its officers have promoted the use of mediation, and have created a mediation facility for use by litigants. High ranking members of the judiciary have extolled the virtues of mediation. Yet interest by lawyers remains low. The mediation facility is underused, and a recent survey of the Malaysian Bar on the subject of mediation conducted by Datuk William Lau and the writer gained a response rate of less than one percent.

Today, however, in some Western jurisdictions mediation has become common in ordinary litigation, and most trial lawyers engage in it. This paper will outline the evolution of mediation in some common law jurisdictions from an idea most lawyers dismissed to a practice most now use. It will highlight the attitudes and actions of lawyers as they have adjusted their practices to include mediation, and adapted mediation to suit their needs. In so doing perhaps it will provide a glimpse into the future in those jurisdictions where mediation is still struggling for acceptance, and a caution about what price might have to be paid for such success.

\section{Evolution - Initiatives and Responses}


Mediation by a third party has of course been used in conflicts since the dawn of history by princes, merchants, religions, families and friends. It is only in the twentieth century however that the practice of mediation was identified as a structured process which could be implemented within the formal legal system. The beginning was in labour relations where mediation was used to avoid disastrous strike action. Gradually the idea spread that such a process could also be beneficial in other legal fields, such as family and criminal law. Academics developed the concept of disputing to supplement the traditional focus on litigation, and began to suggest that mediation and other alternatives to adjudication might be useful in a wide range of cases. For American lawyers, these developments were brought to a head in the "Pound Conference" of 1976, held under the auspices of the organized bar and the judiciary. There, Professor Sander revealed his vision of a "multi-door courthouse" in which mediation was a key alternative to litigation of many types.

The suggestion that disputes could be prevented from becoming lawsuits and dealt with better by mediation was not attractive to lawyers who conducted ordinary litigation. Some specialists such as family lawyers began to accept that consensual dispute resolution might be preferable, but most members of the bar dismissed the idea. Experiments were undertaken such as the creation of community mediation centres and criminal diversion programs, but for most lawyers it was business as usual.

“True believers" in ADR and mediation persisted in their efforts to educate and convince the bar, and academics began offering courses in dispute resolution to law students. As knowledge of mediation and other processes grew amongst lawyers it was suggested that they had a corresponding responsibility to inform their clients. Some jurisdictions mandated that lawyers advise clients of the existence of mediation and other alternatives. Lawyers complied, but most did nothing to encourage their clients to use them.

Judges were more easily persuaded. When they looked at their heavy caseloads and reflected on the inefficiencies of settlement "on the courthouse steps" many became convinced there must be "a better way" and that mediation might be it. One way to ensure that mediation is used more often is to order parties to try it, and many jurisdictions accordingly gave their judiciary this power. Lawyers, as well as mediation supporters, criticized what came to be called mandatory mediation. It was described as unnecessary, unproductive, and a costly addition to the normal process of litigation.

Despite the outcry, mandatory mediation in judge selected cases persisted and proliferated in common law jurisdictions. The most recent development has been to make mediation (or at least some ADR process) a default step in litigation with exemption available only upon a judge's order. Mediation has finally become completely institutionalized within the legal system in many jurisdictions.

Throughout the modern history of mediation sketched above, lawyers have predominantly been opposed to it. Next I will try to analyse this resistance as a mediator might, by reflecting on the interests and concerns that may motivate lawyers' hostility to the idea and practice of mediation.

\section{Role and Identity Concerns}


Lawyers are the recognized experts in litigation, among other legal pursuits. In this role they have traditionally developed paternalistic relationships with their clients - guiding them by virtue of lawyers' superior knowledge of the law and the legal process. When the concept of disputing became current lawyers were pressed to define and defend their role within a wider sphere of conflict than traditional litigation. In response lawyers emphasised their knowledge and skills as strategists and negotiators. They claimed to be experts in dispute resolution by which they meant not only the trial of lawsuits, but their settlement also. This new role as dispute resolvers entailed a new type of relationship with clients, envisaged more as a partnership with a "client centred" focus. Lawyers who promote themselves as expert negotiators often disdain mediation, considering it unnecessary and wasteful for clients. They point to the undoubted fact that the great majority of lawsuits are settled, with or without mediation. This, they assert, shows that lawyers can resolve disputes in their client's interests without outside assistance.

Lawyers have also often been described as the gatekeepers to justice. This aspect of lawyers' identity gives them great prominence in societies that pride themselves on being just. To the extent that mediation embodies a different conception of justice, and a different path to achieve it, lawyers' public esteem is lowered, or at least rivalled by mediators. One vision of mediation offers the hope of consensual justice achieved through empathy and understanding, rather than by the application of law. Some lawyers may be animated by the worry that they are no longer considered by the public to be the sole guardians of justice.

The emphasis in mediation on cooperation and consensus may be troubling to some lawyers because it is at odds with their self-conception as aggressive litigators. Legal education persists in teaching law students that common law litigation is the essence of lawyering, and that winning at trial is the highest professional achievement. It is no wonder that the egos of so many lawyers are bound up with competitive behaviour and besting the adversary. The world of mediation seems a pale imitation of life to these litigators. The self-image of many lawyers is thus incompatible with the cooperative approach required in mediation. Aggressive litigators are also concerned to make sure their colleagues don't think them "soft" by engaging in mediation.

Lawyers may also see mediators as challenging lawyers' traditional role as the dominant party in relationships with clients. In mediation lawyers may fear "losing control" of their client, or at least having to share that control with the mediator. Some mediators have adopted the practice of meeting privately with parties without their lawyers, which fuels this concern. On the other hand, lawyers who find they cannot control the excessive demands of their clients may welcome the moderating influence of a mediator.

Finally, it should be noted that the corollary to many of the above remarks also applies to some lawyers. Those who have embraced ADR find participating in it, or acting as a mediator, to be satisfying and congruent with their self-conception as problem solvers or healers. This group of lawyers is probably, however, still a minority in the profession.

\section{Pecuniary Interests}


The “multi-door courthouse” concept involving mediation represented a clear risk to lawyers' incomes. Disputes that were diverted away from litigation would never generate legal fees. No doubt this pecuniary interest in maintaining their livelihood motivated many lawyers to shun that vision of a justice system.

Plaintiffs' lawyers with contingency fee arrangements find that settlement is preferable to trial and are often more amenable to alternatives. The other side of the coin is that defendant lawyers who bill based on hourly rates do not welcome an early end to litigation.

Most lawyers have accepted mediation in situations where it does not entail loss of business. Thus, “minor disputes" that did not justify legal services may be taken to community mediation services. Similarly for other cases lawyers consider uneconomic or unpalatable such as inmate actions over prison conditions, minor criminal offences, and landlord and tenant disputes. For such cases, mediation is a fine alternative.

Once it was recognized that mediation would not go away, some lawyers took steps to make it part of their business. In many jurisdictions it was suggested that mediators should always be lawyers because acting as a mediator was engaging in the practice of law, particularly when agreements were drafted. Some legal steps were taken against mediators based on the doctrine of "unauthorized practice of law".

Lawyers in big firms with large corporate clients found that these important sources of revenue were becoming ADR friendly. Corporations such as insurers are frequent litigators, and they recognized the value in disposing of litigation in a less costly and time consuming way. The American Center for Public Resources strongly promoted the use of ADR amongst major corporations and law firms. In response, law firms created dispute resolution departments and provided "settlement counsel” to complement their litigation services.

Finally, it should be recognized that a sizable group of lawyers are now engaged in the business of mediation as mediators. These lawyers often serve business sectors in which they have recognized expertise.

\section{Concerns for the Rule of Law}

Concern for the rule of law contributed to the growth of mediation, and has also led to attacks on it. In America in the 1970s there was a perception of a litigation explosion, accompanied by great delays in disposing of cases by trial. Many were concerned that the public, accepting that "justice delayed is justice denied" would lose faith in the courts and the entire legal system. It was imperative to reduce the caseload of courts and speed up the resolution of lawsuits. Mediation seemed appropriate for this task. A desire for more efficiency in the legal system thus animated many early supporters of mediation. As mediation has become institutionalized the expected benefits in reduced cost and time have remained elusive. Nevertheless, it does seem that alternatives such as mediation may have contributed to the continuing decline in the number of trials, thus reducing courts' caseloads. Today few supporters of mediation mention efficiency as one of its virtues. 
The rule of law has also been used in several ways in arguments against mediation. Practicing lawyers often conflate it with the adversary system of justice exemplified by trial and adjudication. For these critics, a trial with a jury is the only way to ensure that truth and justice prevail. We should recognize that this critique is not intended as a justification for the excesses of civil litigation procedure such as interminable and abusive discovery, but rather as positive support for the unique institution of a public trial. Many litigators lament the road to trial but maintain the value of finally arriving there. Any alternative such as mediation that makes the road longer, or offers a detour is to be avoided.

A slightly different critique based on the rule of law is made by those with a more philosophical bent. For them, a public trial and adjudication by a judge is a cornerstone of the justice system and anything that supplants it is wrong in principle. According to this view it is essential that justice be done in public for the public to have knowledge and confidence in law. It is also important for the common law as an evolving body of doctrine to have new precedents established that help to shape society, and keep law in touch with changing social needs and mores. Private settlements cannot accomplish these tasks of adjudication.

Associated with the rule of law is the right to openness of facts of public interest. Some lawyers suggest that settlement via mediation may allow the concealment of information the public should know, such as the existence of hazardous products or business operations.

Finally, legal critics of mediation are concerned about the lack of due process in mediation proceedings. They suggest that disadvantaged parties such as divorcing women, minorities, or consumers suing large corporations may be taken advantage of in mediation by reason of its informality. Coercion to reach a one-sided settlement may occur without the levelling intervention of a judge. There is some evidence that women in divorce mediations receive less monetary value than those going to trial, which seems to substantiate such concerns. The privacy of mediation settlements makes testing this critique difficult.

\section{Adaptation - Expectations and Routine}

Now that mediation has become fully institutionalized in many jurisdictions we can start to answer two important questions: "Will lawyers change their litigation practices?” and, "Will mediation change when integrated into litigation?" Based on the research to date the answer to the first question seems to be "yes" and to the second, "no". For supporters of mediation this appears to be a welcome result, but "the devil is in the details."

Mediation has become part of the routine of lawyers conducting ordinary litigation. However there is growing evidence that it has displaced other settlement efforts by lawyers, resulting in less overall settlement activity. Lawyers let mediators do the settling. This change in practice may result in some cases being settled later than they would have been without mediation. Early mediation has been resisted by lawyers, and this is connected to the type of mediation they expect. We'll examine the evidence on that aspect as part of the discussion on how mediation has been affected by institutionalization. 
Mediation has never been a homogenous field with a shared vision, accepted conceptual structure or consistent terminology. There have always been multiple orientations towards mediation, various models of the mediation process, and different mediator styles. A settlement orientation, "shuttle” process, and an "evaluative" or "pressing” style of mediation practice have been present from the beginning of the modern era of ADR. Accumulating evidence leads to the conclusion that these are what litigating lawyers expect from mediation, and most courts agree with them. In one sense mediation has not changed by its association with the courts. It is just that one vision of mediation has been preferred by lawyers and judges. Today the most frequently practiced form of mediation is probably the settlement oriented evaluative type due to the large number of lawsuits in which it occurs.

If court connected mediation is expected to be evaluative, then it is argued that there must be a basis of fact to evaluate. A rational approach to weighing legal claims considers the provable facts in conjunction with the law to be applied to them. Thus, lawyers have made the case that at least "critical discovery" must be allowed before settlement is attempted. In practice, it appears that the usual discovery is most often completed before mediation occurs. Judges, accustomed to dealing with legally relevant facts, have tended to agree.

Once a client's complaint has been expertly reframed by a lawyer into a legal claim it has proven exceedingly difficult to re-reframe it as a problem to be solved taking into account the client's needs and interests. Most lawyer-mediators probably lack the skill and inclination to even attempt that task. If interest based mediation has not flourished through institutionalization, a transformative approach had even less chance of succeeding in the hands of lawyers. This result should prompt us to reconsider the conceptual categories of conflict, dispute, and legal claim, and what responses are appropriate to each.

The latest development has seen judges and court officers becoming more actively involved in formal settlement processes within the courts. Using public officials has the attraction of not adding additional cost to the litigation process through hiring independent mediators. In some jurisdictions this development has been called judicial settlement conferencing, in others, judicial dispute resolution, and in yet others judge led mediation. It seems inevitable that the type of mediation used in these processes will also usually be evaluative. With the active involvement of judges, however, has come increased scrutiny of the due process aspects of mediation, and the ethics of mediators. These and other issues surrounding judicial dispute resolution are being investigated by an international group of researchers that includes the author.

ADR has been adapted by lawyers to become what might be called ALT - alternative litigation termination, an alternative to trial. Within the traditional legal system it suits lawyers' needs and interests, but the question remains whether it is also best for their clients, or the general public.

\section{Conclusions}

Some conclusions may now be drawn based upon the evolution and adaptation described above: 
1. Ordinary litigation in many jurisdictions is now practiced in the shadow of mediation. Settlement is certain in most cases. However, litigation procedures, notably discovery, have not changed.

This may be the worst possible result for society as a whole which continues to suffer from long and expensive pre-trial procedures which do not culminate in a public display of justice or contribute to the development of the law.

2. There is an evolving understanding of due process in court connected mediation. A mediator's active engagement with the substance of the dispute is an accepted part of the process. Indeed, without that engagement the process may be considered flawed.

The fact that court connected mediations are generally well received by litigants who participate in them shows that the process embodies important elements of procedural justice, at least from the lay perspective. These strengths should be institutionalized.

3. Proponents of mediation as consensual problem solving based on needs and interests, or as a process of personal transformation, should reconsider the project of institutionalizing mediation in the legal system. It seems inevitable that court connected mediation will always be settlement oriented and evaluative in practice.

Instead, these "true believers" should take up the more difficult task of creating a mediation practice and profession that is independent of the legal system and capable of attracting the disputing public directly. In the writer's view this alternative project requires much more research and an academic grounding equal to the law.

4. The "multi-door courthouse" has reverted to a single door leading to a mediation conference room which is more and more often occupied by a judge. Some may well ask whether this structure should still be called a courthouse.

However, if court connected mediation is expected to be evaluative, who better to do that than a sitting judge? We should examine the strengths of judicial dispute resolution and combine it with a revitalized process for bringing appropriate cases to trial.

Let us look for more ways in which mediation in all its many forms may contribute to the betterment of society.

\section{Bibliography}

Abdullah, Abu Haniffa Mohamed. 2008. Amicable Resolution of Civil Litigation in Malaysia. Asia Pacific Mediation Forum Conference, Kuala Lumpur. Available at: http://www.apmec.unisa.edu.au/apmf/2008/papers/17abu\%20haniffa.pdf

Abdullah, Raihana. 2007. A Study of Islamic Family Law in Malaysia: A Select Bibliography. International Journal of Legal Information 35: 514-536. 
Abraham, Cecil. 2006. Alternative Dispute Resolution in Malaysia. ASEAN Law Association $9^{\text {th }}$ General Assembly. Available at: http://www.aseanlawassociation.org/9GAdocs/w4_Malaysia.pdf

Agrios, John A., and Janice A. Agrios. 2004. A Handbook on Judicial Dispute Resolution for Canadian Lawyers. Available online at: http://www.cba.org/alberta/PDF/JDR\%20Handbook.pdf

Alexander, Janet Cooper. 1991. Do the Merits Matter? A Study of Settlements in Securities Class Actions. Stanford Law Review 43: 497-598.

... 1994. Judges’ Self-Interest and Procedural Rules: Comment on Macey. Journal of Legal Studies 23: 647-665.

Alfini, James J. 1986. Alternative Dispute Resolution and the Courts: An Introduction. Judicature 69: 251-314.

... 1999. Risk of Coercion Too Great: Judges Should Not Mediate Cases Assigned to them for Trial. Dispute Resolution Magazine 6: 11-14.

Asian Mediation Association. 2009. Malaysian Mediation Centre. Available at: http://asianmediationassociation.org/AMAmembers_MsiaMC.html

Baruch Bush, Robert A. 1989. Mediation and Adjudication, Dispute Resolution and Ideology: An Imaginary Conversation. Journal of Contemporary Legal Issues 3: 1-35.

Boardman, Michelle E. 2006. Contra Proferentem: The Allure of Ambiguous Boilerplate. Michigan Law Review 104(5): 1105-1128.

Brazil, Wayne D. 2007. Hosting Mediations as a Representative of the System of Civil Justice. Ohio State Journal on Dispute Resolution 22: 227-275.

Brazil, Wayne D., and Jennifer Smith. 1999. Choice of Structures: Critical Values and Concerns Should Guide Format of Court ADR Programs. Dispute Resolution Magazine 6: 8-10.

Brewer, Scott. 1996. Exemplary Reasoning: Semantics, Pragmatics, and the Rational Force of Legal Argument by Analogy. Harvard Law Review 109(5): 923-1028.

Brooker, Penny, and Anthony Lavers. 2005. Mediation Outcomes: Lawyers' Experience with Commercial and Construction Mediation in the United Kingdom. Pepperdine Dispute Resolution Law Journal 5: 161-213.

Brunet, Edward. 2002. Judicial Mediation and Signaling. Nevada Law Journal 3: 232-258.

Bukhari, Khutubul Zaman bin. 2003. Arbitration and Mediation in Malaysia. ASEAN Law Association $8^{\text {th }}$ General Assembly. Available at: http://www.aseanlawassociation.org/docs/w4_malaysia.pdf

Chan, Jeffrey Wah Teck. 2009. Chief Rapporteur Report. ${ }^{\text {st }}$ Asian Mediation Association Conference, Singapore. Available at: http://www.asianmediationassociation.org/conference/pdf/AMA\%20Conference\%202009\%20\%20Chief\%20Rapporteur\%20Report\%20by\%20by\%20Mr\%20Chan\%20Wah\%20Teck\%20Jeffrey.pdf

Charkoudian, Lorig, Cristian De Ritis, Ramona Buck, and Carrie L. Wilson. 2009. Mediation by Any Other Name Would Smell as Sweet - or Would It? The Struggle to Define Mediation and Its Various Approaches. Conflict Resolution Quarterly 26(3): 293-316.

Certilman, Steven A. 2007. Judges as Mediators: Retaining Neutrality and Avoiding the Trap of Social Engineering. Arbitration 73: 24-30. 
Court of Queen's Bench of Alberta. 2004. Consolidated Notices to the Profession. Available online at: http://www.qp.alberta.ca/documents/rules/02_Rules01.pdf

Cratsley, John C. 2006. Judicial Ethics and Judicial Settlement Practices: Time for Two Strangers to Meet. Ohio State Journal on Dispute Resolution 21: 569-596.

Deason, Ellen E. 2005. Procedural Rules for Complementary Systems of Litigation and Mediation - Worldwide. Notre Dame Law Review 80: 553-592.

Della Noce, Dorothy J. 2009. Evaluative Mediation: In Search of Practice Competencies. Conflict Resolution Quarterly 27(2): 193-214.

Dunworth, Terence, and James S. Kakalik. 1994. Preliminary Observations on Implementation of the Pilot Program of the Civil Justice Reform Act of 1990. Stanford Law Review 46: 1303-1337.

Edwards, Harry T. 1986. Alternative Dispute Resolution: Panacea or Anathema? Harvard Law Review 99: 668-684.

Elliott, E. Donald. 1986. Managerial Judging and the Evolution of Procedure. University of Chicago Law Review 53: 306-336.

Fiss, Owen M. 1984. Against Settlement. Yale Law Journal 93: 1073-1090.

Friedman, Gary, and Jack Himmelstein. 2006. Resolving Conflict Together: The Understanding-Based Model of Mediation. Journal of Dispute Resolution 2006: 523-553.

Gabriel, Susan M. 1988. Judicial Participation in Settlement: Pattern, Practice, and Ethics. Ohio State Journal on Dispute Resolution 4: 81-95.

Galanter, Marc. 1985. “... A Settlement Judge, not a Trial Judge:” Judicial Mediation in the United States. Journal of Law \& Society 12(1): 1-18.

... 1986. The Emergence of the Judge as a Mediator in Civil Cases. Judicature 69: 257-262.

..., and Mia Cahill. 1994. "Most Cases Settle”: Judicial Promotion and Regulation of Settlements. Stanford Law Review 46: 1339-1391.

Garth, Bryant. 1993. From Civil Litigation to Private Justice: Legal Practice at War with the Profession and its Values. Brooklyn Law Review 59: 931-960.

Genn, Hazel, Paul Fenn, Marc Mason, Andrew Lane, Nadia Bechai, Lauren Gray, and Dev Vencappa. 2007. Twisting Arms: Court Referred and Court Linked Mediation Under Judicial Pressure. Research Series No. 1/07. Ministry of Justice, London. Available online at: http://www.nottingham.ac.uk/business/cris/papers/107\%20Twisting\%20Arms\%20-\%20Mediation\%20Report\%20-\%20Genn\%20(1).pdf

Goldberg, Steven H. 1997. “Wait a Minute. This Is Where I Came In.”: A Trial Lawyer’s Search for Alternative Dispute Resolution. BYU Law Review 1997: 653-685.

Goldfien, Jeffrey H., and Jennifer K. Robbennolt. 2007. What if Lawyers Have Their Way? An Empirical Assessment of Conflict Strategies and Attitudes Toward Mediation Styles. Ohio State Journal on Dispute Resolution 22: 277-319. 
Gould, Nicholas, Claire King, and Philip Britton. 2010. Mediating Construction Disputes: An Evaluation of Existing Practice. King’s College London, Centre of Construction Law \& Dispute Resolution. Available online at: http://www.kcl.ac.uk/content/1/c6/06/13/33/KCLMediatingConstructionPartsI-III.pdf

Guill, James L. and Edward A. Slavin Jr. 1989. Rush to Unfairness: The Downside of ADR. Judges Journal 28: 945.

Hensler, Deborah R. 2002. Suppose It's Not True: Challenging Mediation Ideology. Journal of Dispute Resolution 2002: 81-99.

... 2003. Our Courts, Ourselves: How the Alternative Dispute Resolution Movement is Re-Shaping Our Legal System. Pennsylvania State Law Review 108: 165-197.

Hermann, Michele G. 1990. The Dangers of ADR: A Three-Tiered System of Justice. Journal of Contemporary Legal Issues 3: 117-123.

Hoffman, David. A. 2005. Courts and ADR: A Symbiotic Relationship. Dispute Resolution Magazine 11: 2.

Holland, Kenneth M. 1978. William J. Campbell: Case Study of an Activist U.S. District Judge. Justice System Journal 3: 143-162.

Ingleby, Richard. 1993. Court Sponsored Mediation: The Case Against Mandatory Participation. Modern Law Review 56: 441-451.

Joseph, Daniel, and Michelle L. Gilbert. 1989. Breaking the Settlement Ice: The Use of Settlement Judges in Administrative Proceedings. Administrative Law Journal 3: 571-600.

Killefer, Campbell. 2009. Wrestling with the Judge Who Wants You to Settle. Litigation 35(3): 17-22.

Kressel, Kenneth, Edward A. Frontera, Samuel Forlenza, Frances Butler, and Linda Fish. 1994. The SettlementOrientation vs. The Problem-Solving Style in Custody Mediation. Journal of Social Issues 50: 67-84.

Lande, John. 1997a. How Will Lawyering And Mediation Practices Transform Each Other? Florida State University Law Review 24: 839-901.

... 1997b. Relationships Drive Support for Mediation. Alternatives to the High Cost of Litigation 15(7): 95-97

... 1998a. Failing Faith In Litigation? A Survey Of Business Lawyers' And Executives' Opinions. Harvard Negotiation Law Review 3: 1- 70.

... 1998b. Lawyers' Routine Participation Directs Shape Of 'Liti-Mediation'. Alternatives to the High Cost of Litigation 16: 53-59.

... 2000. Getting the Faith: Why Business Lawyers And Executives Believe In Mediation. Harvard Negotiation Law Review 5: 137-231.

... 2004. Commentary: Focusing on Program Design Issues in Future Research on Court-Connected Mediation. Conflict Resolution Quarterly 22: 89-100.

... 2006. How Much Justice Can We Afford?: Defining the Courts' Roles and Deciding the Appropriate Number of Trials, Settlement Signals, and Other Elements Needed to Administer Justice. Journal of Dispute Resolution 2006: 213-252. 
... 2008. The Movement Toward Early Case Handling in Courts and Private Dispute Resolution. Ohio State Journal on Dispute Resolution 24: 81-129.

Lee, Swee Seng. 2005. Mediation: Its Practice \& Procedure. Available at: http://leesweeseng.com/newsletter_01_02feb05.asp

... 2007. Mediation in Resolving Disputes in Medical Negligence Cases. Available at: http://leesweeseng.com/newsletter_19Mar07-03.asp

Lieberman, Jethro K., and James F. Henry. 1986. Lessons from the Alternative Dispute Resolution Movement. University of Chicago Law Review 53: 424-439.

Lubet, Steven. 1989. Some Early Observations on an Experiment with Mandatory Mediation. Ohio State Journal on Dispute Resolution 4: 235-254.

Lynch, Eugene F., and Lawrence C. Levine. 1988. The Settlement of Federal District Court Cases: A Judicial Perspective. Oregon Law Review 67: 239-252.

Macey, Jonathan R. 1994. Judicial Preferences, Public Choice, and the Rules of Procedure. Journal of Legal Studies 23: 627-646.

Macfarlane, Julie. 2002. Culture Change? A Tale of Two Cities and Mandatory Court-Connected Mediation. Journal of Dispute Resolution 2002: 241-325.

... 2008. The New Lawyer: How Settlement is Transforming the Practice of Law. Vancouver: University of British Columbia Press.

Malaysian Mediation Centre. 2010. Website.

http://www.malaysianbar.org.my/malaysian_mediation_centre_mmc.html

McAdoo, Bobbi. 2007. All Rise, the Court is in Session: What Judges Say About Court-Connected Mediation. Ohio State Journal on Dispute Resolution 22: 377-442.

McAdoo, Bobbi, and Art Hinshaw. 2002. The Challenge of Institutionalizing Alternative Dispute Resolution:

Attorney Perspectives on the Effect of Rule 17 on Civil Litigation in Missouri. Missouri Law Review 67: 473-593.

McEwen, Craig A. 1991. Pursuing Problem-Solving or Predictive Settlement. Florida State University Law Review 19: 77-88.

..., and Richard J. Maiman. 1981. Small Claims Mediation in Maine: An Empirical Assessment. Maine Law Review 33: 237-268.

Menkel-Meadow, Carrie. 1985. For and Against Settlement: Uses and Abuses of the Mandatory Settlement Conference. UCLA Law Review 33: 485-514.

... 1991. Pursuing Settlement in an Adversary Culture: A Tale of Innovation Co-opted or "The Law of ADR”. Florida State University Law Review 19: 1-46.

Millhauser, Marguerite. 1987. The Unspoken Resistance to Alternative Dispute Resolution. Negotiation Journal 1987: 29-35.

Mokhtar, Khairil Azmin. 2010. Challenging Time for Legal Fraternity After Amendments. Blog. http://blogs.iium.edu.my/ka mokhtar/2010/01/03/challenging-time-for-legal-fraternity-after-amendments/ 
Murray, John S. 1987. Lawyers and Alternative Dispute Resolution Success. Pepperdine Law Review 14: 781-785.

Note. 1990. Mandatory Mediation and Summary Jury Trial: Guidelines for Ensuring Fair and Effective Processes. Harvard Law Review 103: 1086-1104.

... 2000. Developments in the Law: The Paths of Civil Litigation. Harvard Law Review 113: 1752-1875.

Ooi, Christina S. S. 2005. The Role of Lawyers in Mediation: What the Future Holds. Available at:

http://www.malaysianbar.org.my/adr_arbitration_mediation/the_role_of_lawyers_in_mediation_what the_future_ho $\underline{\text { lds.html }}$

Otis, Louise, and Eric H. Reiter. 2006. Mediation by Judges: A New Phenomenon in the Transformation of Justice. Pepperdine Dispute Resolution Law Journal 6: 351-403.

Parry, David R. 2010. The Use of Facilitative Dispute Resolution in the State Administrative Tribunal of Western Australia - Central Rather Than Alternative Dispute Resolution in Planning Cases. Environmental and Planning Law Journal 27: 113-130.

Picard, Cheryl. 2002. Common Language, Different Meaning: What Mediators Mean when they Talk About their Work. Negotiation Journal 2002: 251-269.

Poitras, Jean, Arnaud Stimec, and Jean-François Roberge. 2010. The Negative Impact of Attorneys on Mediation Outcomes: A Myth or Reality? Negotiation Journal 26(1): 9-24. Available online at: http://www.negotiationlawblog.com/uploads/file/The\%20Negative\%20Impact\%20of\%20Attorneys\%20on\%20Medi ation\%20Outcomes\%20--\%20A\%20Myth\%20or\%20a\%20Reality.pdf

Posner, Richard A. 1986. The Summary Jury Trial and Other Methods of Alternative Dispute Resolution: Some Cautionary Observations. University of Chicago Law Review 53: 366-393.

Raynes, Arthur G. 1989. ...But Is It Good for the Plaintiff? Brief 18: 15-38.

Resnik, Judith. 1982. Managerial Judges. Harvard Law Review 96: 374-514.

... 1986. Failing Faith: Adjudicatory Procedure in Decline. University of Chicago Law Review 53: 494-560.

Reuben, Richard C. 1997. Public Justice: Toward a State Action Theory of Alternative Dispute Resolution. California Law Review 85: 577-641.

Riskin, Leonard L., and Nancy A. Welsh. Is That All There Is?: “The Problem” in Court-Oriented Mediation. George Mason Law Review 15: 863-932.

Robinson, Peter. 2006. Adding Judicial Mediation to the Debate about Judges Attempting to Settle Cases Assigned to Them for Trial. Journal of Dispute Resolution 2006: 335-385.

Rooke, John D. 2009. Improving Excellence: Evaluation of the Judicial Dispute Resolution Program in the Court of Queen's Bench of Alberta. On file with the author.

Rosenberg, Joshua D., and H. Jay Folberg. 1994. Alternative Dispute Resolution: An Empirical Analysis. Stanford Law Review 46: 1487-1551. 
Sabatino, Jack M. 1998. ADR as “Litigation Lite”: Procedural and Evidentiary Norms Embedded Within Alternative Dispute Resolution. Emory Law Journal 47: 1289-1349.

Sander, Frank E. A. 1976. The Multi-Door Courthouse: Settling Disputes in the Year 2000. Barrister 3: 18-42.

... 1999. A Friendly Amendment. Dispute Resolution Magazine 6: 11-24.

Schuck, Peter H. 1986. The Role of Judges in Settling Complex Cases: The Agent Orange Example. University of Chicago Law Review 53: 337-365.

Shaw, Lori Anne. 2010. Divorce Mediation Outcome Research: A Meta-Analysis. Conflict Resolution Quarterly 27: 447-467.

Sherman, Edward F. 1996. The Impact on Litigation Strategy of Integrating Alternative Dispute Resolution into the Pretrial Process. Review of Litigation 15: 503-524.

Sternlight, Jean R. 2003. ADR is Here: Preliminary Reflections on Where it Fits in a System of Justice. Nevada Law Journal 3: 289-304.

... 2007. Is Alternative Dispute Resolution Consistent with the Rule of Law?: Lessons from Abroad. DePaul Law Review 56: 569-592.

Tyler, Tom R. 1989. The Quality of Dispute Resolution Procedures and Outcomes: Measurement Problems and Possibilities. Denver University Law Review 66: 419-436.

Wall, James A. Jr., and Suzanne Chan-Serafin. 2009. Processes in Civil Case Mediations. Conflict Resolution Quarterly 26: 261-291.

... 2010. Do Mediators Walk Their Talk in Civil Cases? Conflict Resolution Quarterly 28: 3-21.

Weinstein, Jack B. 1986. Warning: Alternative Dispute Resolution may be Dangerous to your Health. Litigation 12: $5-50$.

Welsh, Nancy A. 2001a. The Thinning Vision of Self-Determination in Court-Connected Mediation: The Inevitable Price of Institutionalization? Harvard Negotiation Law Review 6: 1-96.

... 2001b. Making Deals in Court-Connected Mediation: What's Justice Got To Do With It? Washington University Law Quarterly 79: 787-861.

Winter, Ralph K. 1992. In Defense of Discovery Reform. Brooklyn Law Review 58: 263-278.

Wissler, Roselle L. 2002. Court-Connected Mediation in General Civil Cases: What We Know from Empirical Research. Ohio State Journal of Dispute Resolution 17: 641-703.

.... 2004. The Effectiveness of Court-Connected Dispute Resolution in Civil Cases. Conflict Resolution Quarterly 22: 55-88. 